\title{
Ice-shelf basal melting in a global finite-element sea-ice/ice-shelf/ocean model
}

\author{
R. TIMMERMANN, Q. WANG, H.H. HELLMER \\ Alfred Wegener Institute for Polar and Marine Research, Bremerhaven, Germany \\ E-mail: Ralph.Timmermann@awi.de
}

\begin{abstract}
The Finite Element Sea-ice Ocean Model (FESOM) has been augmented by an ice-shelf component with a three-equation system for diagnostic computation of boundary layer temperature and salinity. Ice-shelf geometry and global ocean bathymetry have been derived from the RTopo-1 dataset. A global domain with a triangular mesh and a hybrid vertical coordinate is used. To evaluate sub-iceshelf circulation and melt rates for present-day climate, the model is forced with NCEP reanalysis data. Basal mass fluxes are mostly realistic, with maximum melt rates in the deepest parts near the grounding lines and marine ice formation in the northern sectors of the Ross and Filchner-Ronne Ice Shelves, Antarctica. Total basal mass loss for the ten largest ice shelves reflects the importance of the Amundsen Sea ice shelves; the Getz Ice Shelf is shown to be a major meltwater contributor to the Southern Ocean. Despite their modest melt rates, the 'cold water' ice shelves in the Weddell Sea are still substantial sinks of continental ice in Antarctica. Discrepancies between the model and observations can partly be attributed to deficiencies in the forcing data or to (sometimes unavoidable) smoothing of ice-shelf and bottom topographies.
\end{abstract}

\section{INTRODUCTION}

Melting of glaciers, ice caps and ice sheets contributes to changes in global sea level. Therefore, an estimate of the rate of ice mass loss from the Antarctic ice sheet is an important component of the Intergovernmental Panel on Climate Change (IPCC)'s Fifth Assessment Report. Given that most of the Antarctic ice sheet drains into floating glaciers or ice shelves, an understanding of sub-ice-shelf processes is crucial to obtain a reliable estimate of the Southern Hemisphere's ice mass budget. The European Union project ice2sea was set up to reduce uncertainties in projections of the cryosphere's contribution to global sea-level rise. The development of improved models of ocean/ice-shelf interaction is an important component of this.

Modelling of processes in sub-ice-shelf cavities and the quantification of ice-shelf basal melt rates in an Antarctic circumpolar context go back to the Bremerhaven Regional Ice-Ocean Simulations (BRIOS; Beckmann and others, 1999; Timmermann and others, 2001, 2002a,b; Assmann and others, 2003; Hellmer, 2004). Although resolution in these simulations was relatively coarse and many features of ice-shelf morphology and cavity topography were unknown then, a comparison with results of smallerscale regional/local models (e.g. Gerdes and others, 1999; Grosfeld and others, 2001; Williams and others, 2001; Thoma and others, 2006; Dinniman and others, 2007) shows that BRIOS results are, to a large extent, realistic.

To overcome the limitations of a relatively coarse resolution and the open boundaries inherent to any regional model, and at the same time to include newly obtained information about many details of cavity geometry, we developed a finite-element sea-ice/ice-shelf/ocean model with a global domain, a hybrid vertical coordinate and a horizontal mesh focused on the Southern Ocean continental shelf including the sub-ice-shelf cavities. Here we report on the achievements in the development of this member of a new generation of ice-shelf/ocean models. For validation purposes, we conducted simulations forced with NCEP (US
National Centers for Environmental Prediction) reanalysis data. Sub-ice-shelf circulation and melt rates for presentday climate are evaluated and compared to other model simulations (with the BRIOS model serving as one of the baseline datasets) and to observation-based estimates. We discuss the model representation of the larger ice shelves and look into possible reasons for discrepancies.

\section{MODEL DESCRIPTION}

The Finite Element Sea-ice Ocean Model (FESOM; Timmermann and others, 2009) has been augmented by a newly implemented ice-shelf component. We use a three-equation system to compute temperature and salinity in the boundary layer between ice and ocean and the melt rate at the ice-shelf base as proposed by Hellmer and Olbers (1989) and refined by Holland and Jenkins (1999). Turbulent fluxes of heat and salt are computed with coefficients depending on the friction velocity, following Jenkins (1991). As with most models of ice-shelf/ocean interaction, we assume a steady state for iceshelf thickness and cavity geometry; on timescales covered by the simulation, basal mass loss is assumed to be in equilibrium with surface accumulation and the divergence of the ice-shelf flow field.

We use a tetrahedral mesh with a horizontal length scale of $50 \mathrm{~km}$ along non-Antarctic coasts, which is refined to $10 \mathrm{~km}$ along the Antarctic coast, $7 \mathrm{~km}$ under the larger ice shelves in the Ross and Weddell Seas and $4 \mathrm{~km}$ under the small ice shelves in the Amundsen Sea. While mesh size varies between 30 and $40 \mathrm{~km}$ in the offshore Southern Ocean, it increases to $\sim 250-300 \mathrm{~km}$ in the vast basins of the Atlantic and Pacific Oceans. Model resolution is also high in some of the narrow straits that are important to global thermohaline circulation: the Strait of Gibraltar, Fram and Denmark Straits, and the region between Iceland and Scotland. In total the grid comprises $\sim 2 \times 10^{6}$ grid nodes.

To allow an adequate representation of sub-ice-shelf cavities and at the same time obtain a realistic global 


\section{a}
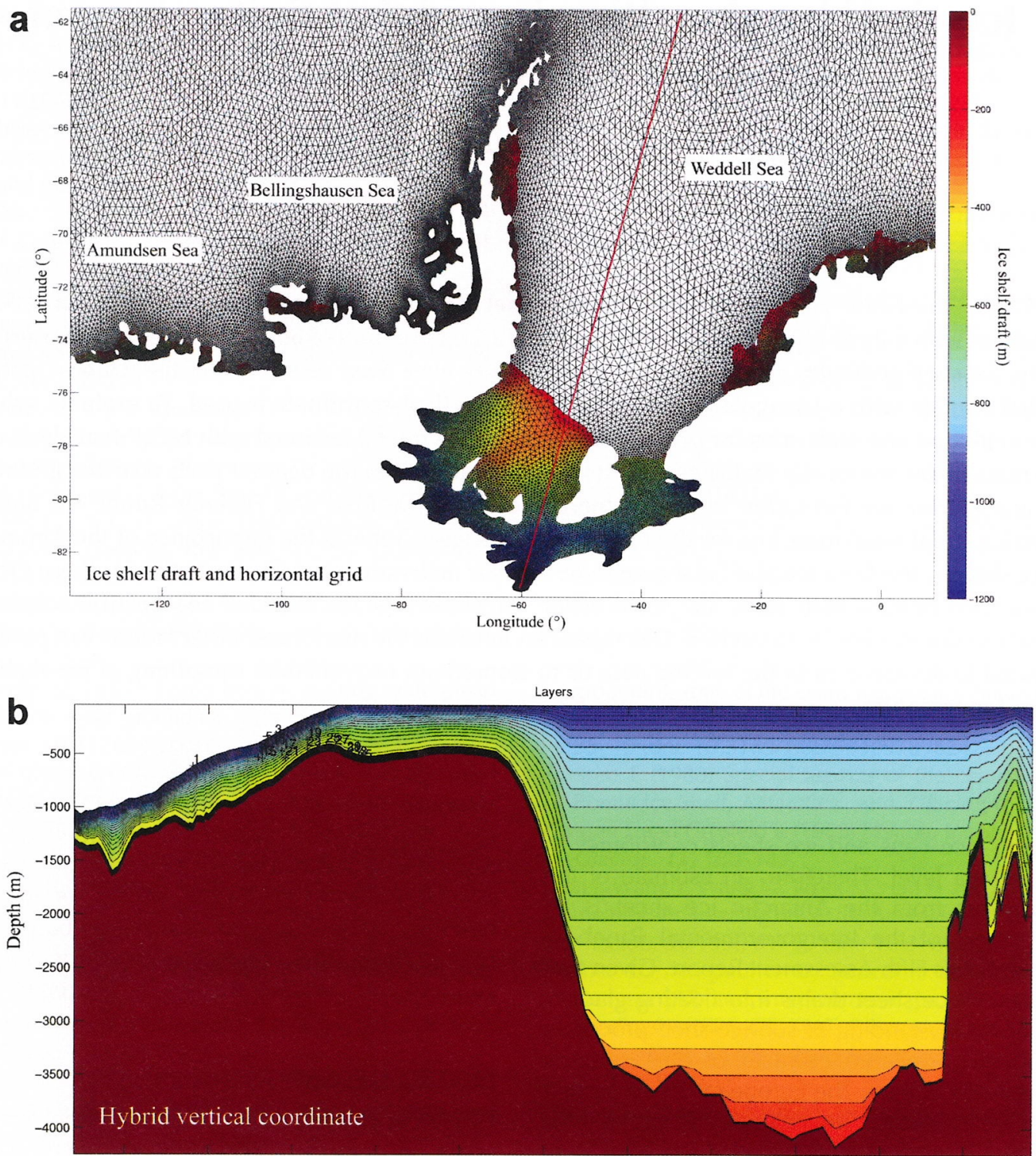

Fig. 1. (a) Ice-shelf draft and horizontal grid in the Amundsen, Bellingshausen and Weddell Seas of the global model. (b) Vertical coordinate levels on a section from the Ronne Ice Shelf cavity to the northeast. The red line in (a) indicates the section location.

thermohaline circulation, we use a hybrid vertical coordinate system with 36 layers and a z-level discretization in the mid- and low-latitude ocean basins, while the top 23 layers use terrain-following coordinates (sigma layers) along the Antarctic coast for depths shallower than $2500 \mathrm{~m}$ (Fig. 1). Even in the $z$-coordinate region, bottom nodes are allowed to deviate from their nominal layer depth in order to facilitate a correct representation of bottom topography. Bottom elements conform to the shape of the sea floor in a way that is akin to the shaved-cells approach in finite-difference models.

Ice-shelf draft, cavity geometry and global ocean bathymetry have been derived from the RTopo- 1 dataset (Timmermann and others, 2010) and thus include data from many of the most recent surveys of the Antarctic continental shelf. A Gaussian function with a width depending on the model's horizontal resolution is applied to smooth ice-shelf draft and sea floor topography in the sigma-coordinate region.

For this study we force the model with daily data from the NCEP/NCAR (US National Center for Atmospheric Research) reanalysis for the period 1958-2010. We use the $10 \mathrm{~m}$ wind, $2 \mathrm{~m}$ air temperature and specific humidity, total cloudiness and net precipitation to compute surface wind stress, turbulent sensible and latent heat fluxes, and longand shortwave radiation. Details of the forcing strategy are described by Timmermann and others (2009).

Initial temperature and salinity fields have been derived from the US National Oceanic and Atmospheric Administration (NOAA)'s World Ocean Atlas 2001 and extended into the ice-shelf cavities using inter-/extrapolation based on minimizing the cost function

$$
J(\Theta)=(d-M \Theta)(d-M \Theta)^{\top}+(\nabla \Theta) W_{\nabla}(\nabla \Theta)^{\top}
$$

where $d$ represents the original data (WOA 2001 in our case), $\Theta$ is the data vector on model gridpoints, $M$ is a mapping operator that projects data from the model to the atlas grid and $W_{\nabla}$ represents the smoothing weights. The aim of this approach is to keep the difference between the mapped fields and the data small wherever data exist, and to minimize gradients otherwise (personal communication from D. Sidorenko, 2011). 


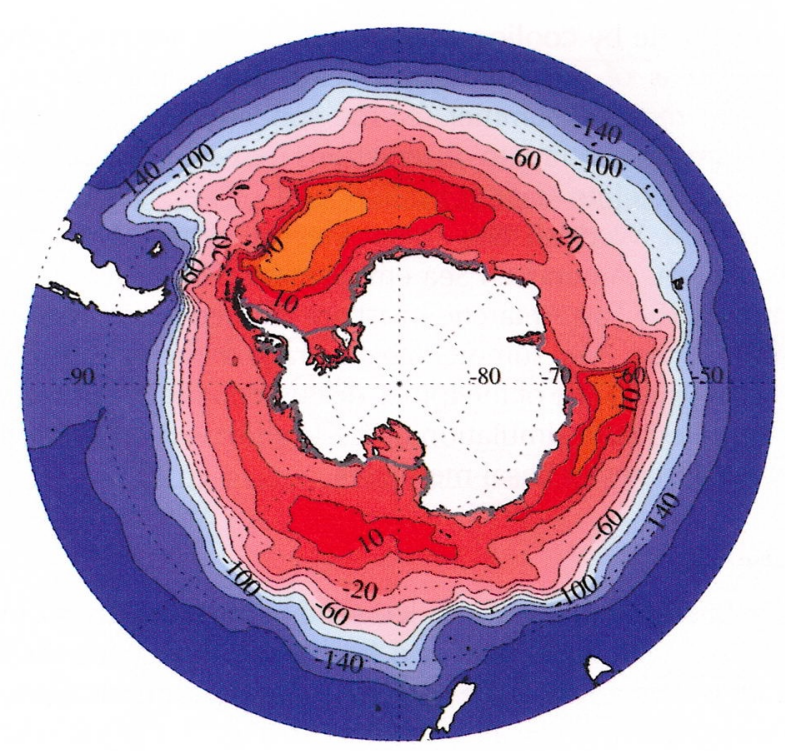

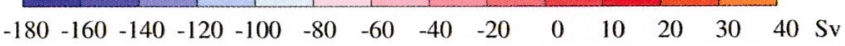

Fig. 2. Simulated mean barotropic stream function in the Southern Ocean of the global finite-element sea-ice/ice-shelf/ocean model for the period 1980-99.

\section{RESULTS}

\section{Ocean circulation and sea-ice distribution}

Like the coarse-scale FESOM simulations of Timmermann and others (2009), the model reproduces many features of ocean circulation and sea-ice distribution in good agreement with observations. A map of the simulated barotropic stream function (Fig. 2) shows the three subpolar gyres, with transports of $39 \mathrm{~Sv}$ for the Weddell Gyre, $25 \mathrm{~Sv}$ for the Kerguelen Gyre and $18 \mathrm{~Sv}$ for the Ross Gyre. Modelled transport of the Antarctic Circumpolar Current (ACC) through Drake Passage is $150 \mathrm{~Sv}$.

Simulated bottom temperatures in the Southern Ocean (Fig. 3) averaged over the period 1980-99 agree well with data from the World Ocean Atlas 2001. High Salinity Shelf Water (HSSW) produced on the Weddell Sea continental shelf at the surface freezing point initiates the formation of Weddell Sea Deep and Bottom Water (WSDW/WSBW) that fills the deep basin of the Weddell Sea and partly spreads into the Atlantic and Indian Oceans as Antarctic Bottom Water (AABW). Minimum temperature modelled for the central Weddell Sea basin is about $-0.7^{\circ} \mathrm{C}$, which compared to observations of Fahrbach and others (2011) is slightly too high. Cold shelf waters produced in the Ross Sea leave the area with the coastal current towards Terre Adélie, so that Ross Sea bottom water is not replenished (at a sufficient rate) in the model.

While the temperature maximum associated with the coastal current in the Weddell Sea is reproduced well $\left(0.3^{\circ} \mathrm{C}\right.$ bottom temperature at the shelf break in the

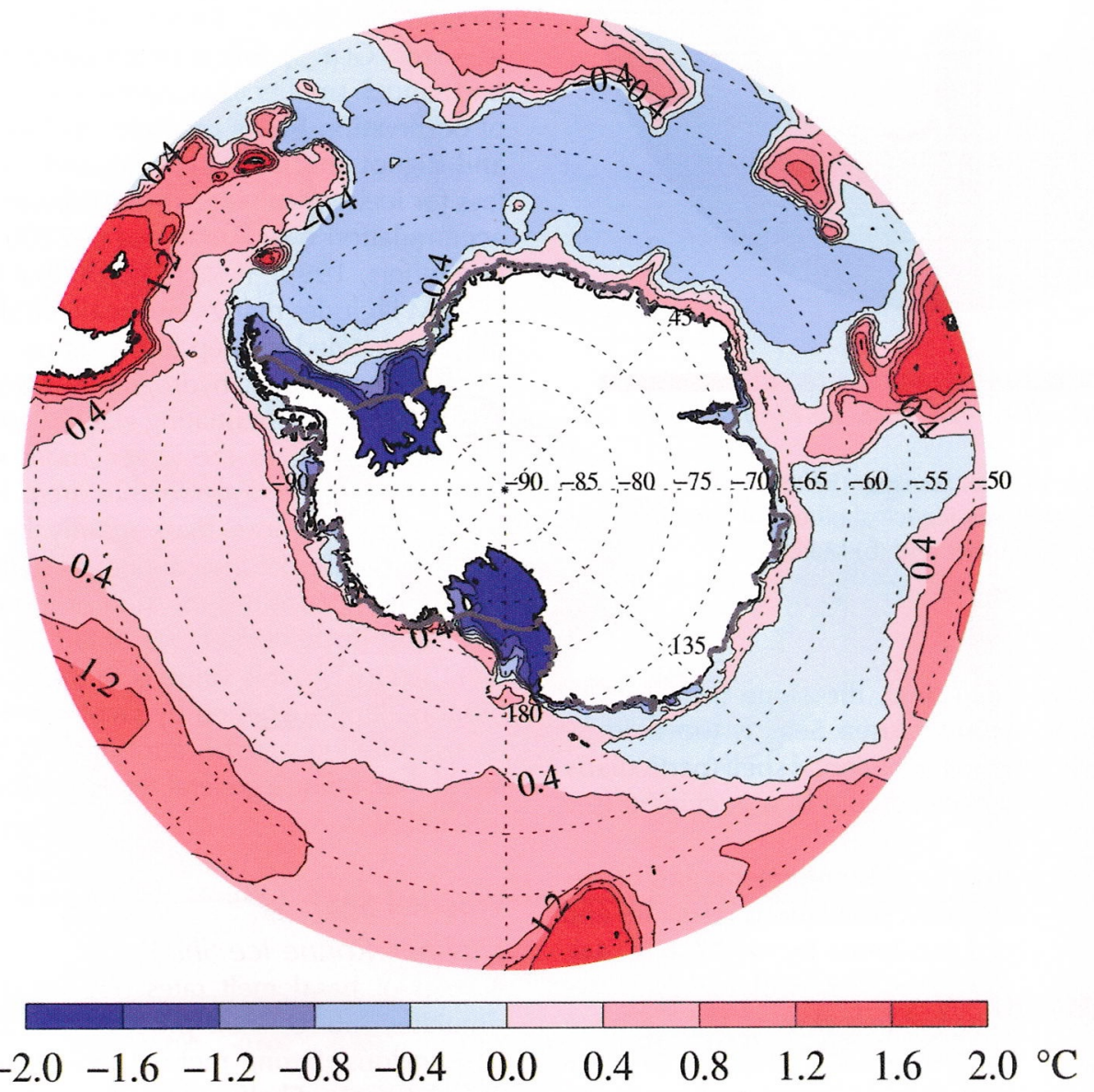

Fig. 3. Simulated mean bottom temperature in the Southern Ocean of the global finite-element sea-ice/ice-shelf/ocean model for the period 1980-99. 

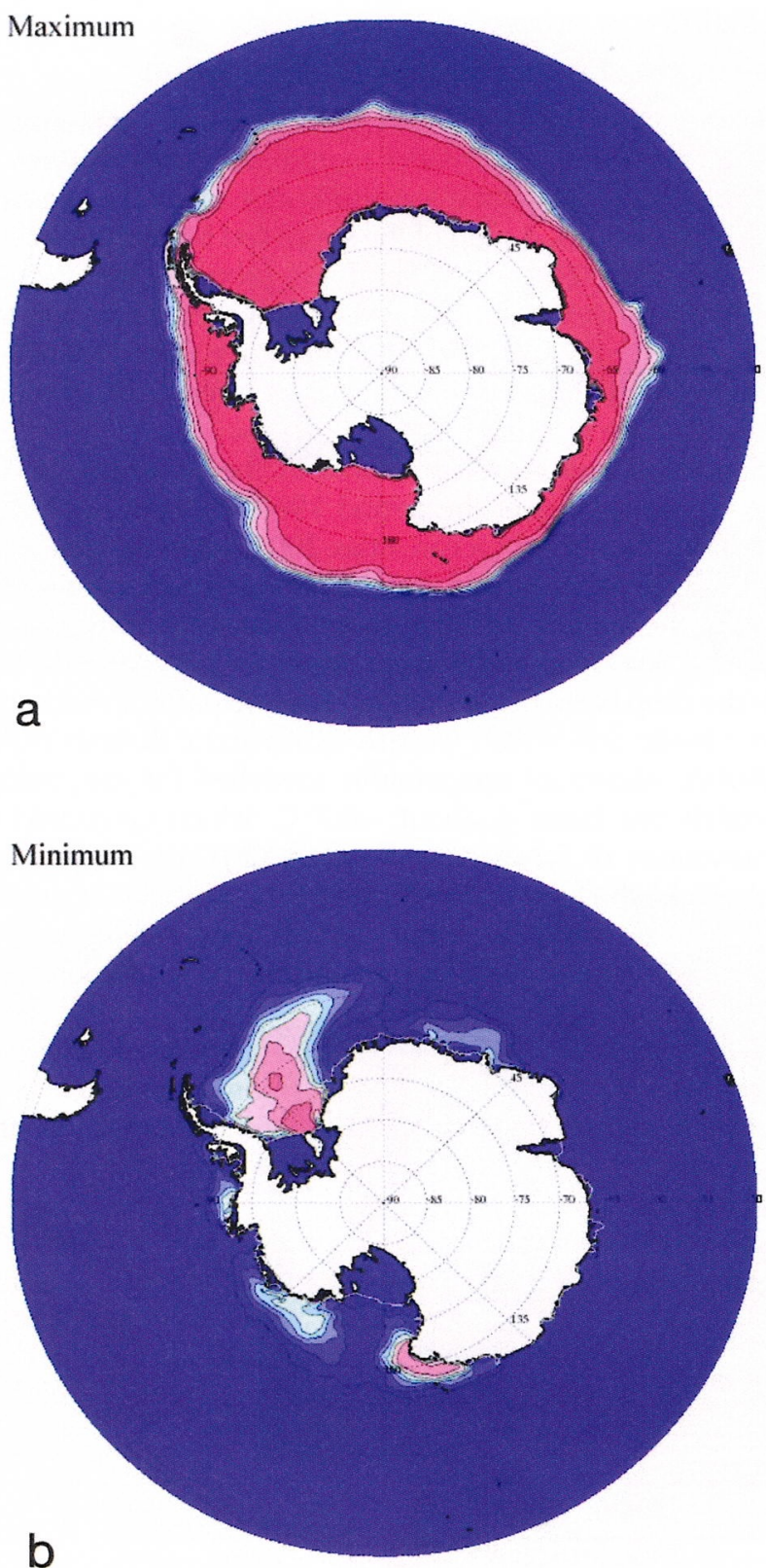

$\begin{array}{lllllllllll}0 & 0.1 & 0.2 & 0.3 & 0.4 & 0.5 & 0.6 & 0.7 & 0.8 & 0.9 & 1\end{array}$

Fig. 4. Simulated mean sea-ice coverage in the Southern Ocean of the global finite-element sea-ice/ice-shelf/ocean model for the period 1980-99 for (a) September and (b) March.

eastern/southeastern Weddell Sea), the slope front current in the Amundsen and Bellingshausen Seas is too cold by $\sim 0.8^{\circ} \mathrm{C}$. For the Amundsen Sea continental shelf (particularly in Pine Island Bay), a pronounced cold bias is evident (see below).

Compared to the experiments of Timmermann and others (2009), winter sea-ice extent in our simulations is smaller and underestimates the observed maximum by $\sim 10 \%$ (Fig. $4 \mathrm{a}$ ), while summer sea-ice extent has increased and is closer to reality now. Sensitivity studies (not shown) enable us to attribute the improved summer sea-ice coverage to (1) a slightly modified parameterization of lateral melting in the sea-ice model and (2) the implementation of ice shelves which (as shown by Hellmer, 2004) cause an increase in sea-ice volume by cooling and freshening the waters in the marginal seas of the Southern Ocean. For many regions, however, simulated summer sea-ice concentration (Fig. 4b) remains small. Contrary to observations derived from passive microwave satellite data (Cavalieri and others, 2006), the northwestern Weddell Sea (near the tip of the Antarctic Peninsula), the Amundsen Sea embayment (Pine Island Bay) and most of the East Antarctic coast are ice-free in summer in our simulations. Also summer ice coverage in the Ross Sea is underestimated. One of the topics discussed in this section is how this affects the simulation of ice-shelf/ocean interaction and the estimates of basal melt rates.

\section{Ice shelves}

Despite the fact that initial sub-ice-shelf hydrography is not in equilibrium with basal heat and freshwater fluxes, ice-shelf basal melt rates for most ice shelves approach a quasi-steady state within the first 5 years of integration (Fig. 5). Only for the Filchner-Ronne Ice Shelf, with its complex horizontal circulation and deep grounding line, do we find a flushing (water mass replacement) timescale of $\sim 10$ years. After the initial adjustment, interannual variability is dominated by variations in summer melt rate and mostly remains within a range $\pm 20 \%$. Variability on longer (decadal) timescales is most pronounced for the Getz and Ross Ice Shelves and (in contrast to year-to-year variability) determined by trends in winter melt rate. This long-term behaviour may still be part of model adjustment processes in the deep ocean, but it may also be due to a (possibly realistic) trend in the atmospheric forcing.

Melt rates from FESOM, BRIOS and various other sources (observations and regional high-resolution models) are compiled in Table 1. Total ice-shelf basal melting in FESOM is $\sim 1600 \mathrm{Gta}^{-1}$; this is much more than in BRIOS (which had a much smaller total ice-shelf area), well above the range of observation-based estimates by Jacobs and others (1996) and Rignot and Jacobs (2008), and it certainly would leave less for iceberg calving when considering present-day snow accumulation over Antarctica $\left(\sim 2200 \mathrm{Gta}^{-1}\right.$; e.g. Vaughan and others, 1999). Note, though, that total basal melting in FESOM includes many very small ice shelves along the coast that we decided to keep in the set-up, although they are too small to have local hydrography resolved in an adequate way. Typically these floating glaciers are much more exposed to ocean heat than the larger, more secluded ice shelves; they add up to a considerable area. In reality, these small ice shelves will lose mass mainly by calving of icebergs, while in the model they appear as areas of basal melting.

If we only consider the sum of the ten larger ice shelves discussed in this paper, we obtain an integrated mass loss of $1130 \mathrm{Gta}^{-1}$. This value is in the upper range of ice-shelf basal melting suggested by Jacobs and others (1996). Some excess melting can be attributed to two particular issues rather than being a general tendency in our model simulation (see below).

\section{Weddell Sea}

\section{Filchner-Ronne Ice Shelf}

A map of basal melt rates (Fig. 6) indicates that FESOM simulates sub-ice-shelf processes in good agreement with observations. Strong melting (up to $2 \mathrm{~m} \mathrm{a}^{-1}$ ) occurs under the Filchner Ice Shelf south of Berkner Island and particularly (up to $7 \mathrm{~m} \mathrm{a}^{-1}$ ) in the deepest part of the cavity close to the grounding line, where the ice base reaches $1200 \mathrm{~m}$ below 
Weddell Sea

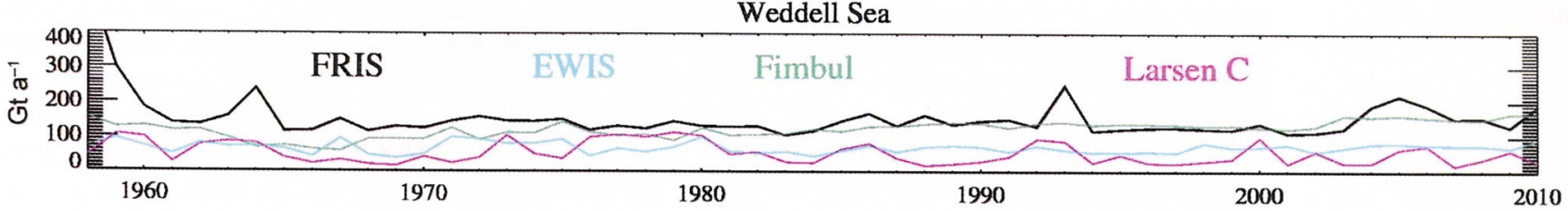

Amundsen/Bellingshausen Seas
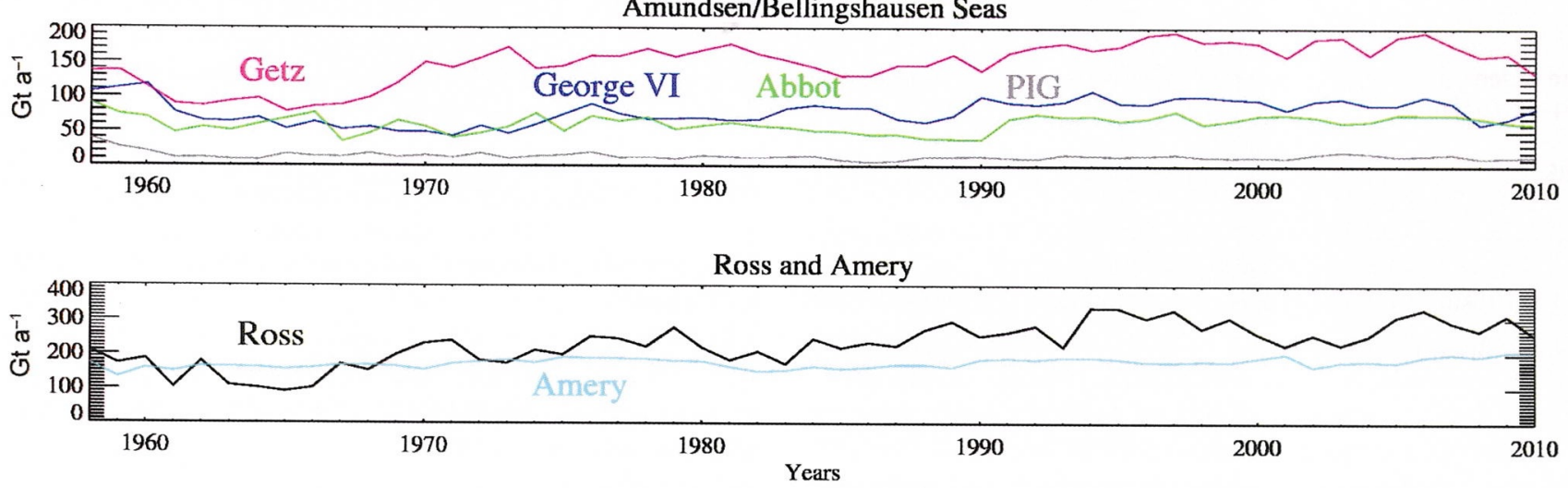

Fig. 5. Annual means of ice-shelf basal mass loss $\left(\mathrm{Gta}^{-1}\right)$ for various sectors of the Southern Ocean in the FESOM hindcast simulation Note the varying $y$-axis ranges.
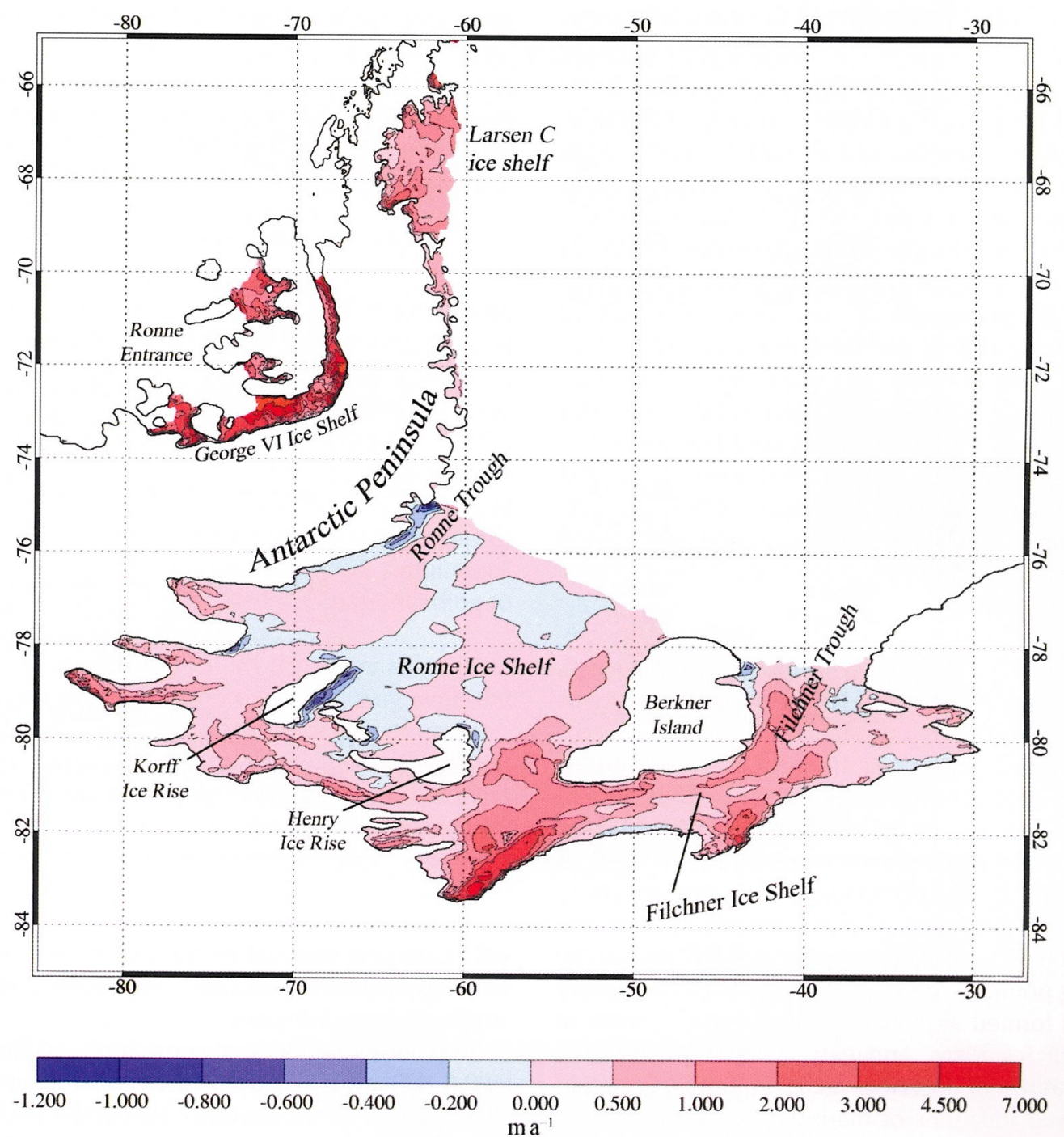

Fig. 6. Basal melt rates $\left(\mathrm{ma}^{-1}\right)$ for the Filchner-Ronne, Larsen $\mathrm{C}$ and George VI Ice Shelves averaged over 20 years of model simulation (1980-99). Note the nonlinear colour scale. 
Table 1. Characteristics of the larger Antarctic ice shelves from FESOM (average over 1980-99), BRIOS (Hellmer, 2004) and other sources. Bold: basal mass loss; italic: area-mean melt rate; roman: ice-shelf area. 'Sum of ten' refers to the ten larger ice shelves considered in this study. Areas in the left column are derived from RTopo-1 (Timmermann and others, 2010)

\begin{tabular}{|c|c|c|c|}
\hline & $\begin{array}{c}\text { FESOM } \\
\text { (this study) }\end{array}$ & $\begin{array}{c}\text { BRIOS } \\
\text { (Hellmer, 2004) }\end{array}$ & Other estimates \\
\hline $\begin{array}{l}\text { All } \\
1494 \times 10^{3} \mathrm{~km}^{2}\end{array}$ & $\begin{array}{c}1600 \mathrm{Gta}^{-1} \\
1510 \times 10^{3} \mathrm{~km}^{2}\end{array}$ & $\begin{array}{c}907 \mathrm{Gt} \mathrm{a}^{-1} \\
1233 \times 10^{3} \mathrm{~km}^{2}\end{array}$ & $1030 \mathrm{Gta}^{-1}$ (Rignot and Jacobs, 2008) \\
\hline $\begin{array}{l}\text { Sum of ten } \\
1244 \times 10^{3} \mathrm{~km}^{2}\end{array}$ & $\begin{array}{c}1130 \mathrm{Gta}^{-1} \\
1261 \times 10^{3} \mathrm{~km}^{2}\end{array}$ & $\begin{array}{c}\mathbf{8 6 0} \mathrm{Gta}^{-1} \\
1183 \times 10^{3} \mathrm{~km}^{2}\end{array}$ & $756 \pm 380 \mathrm{Gta}^{-1}$ (Jacobs and others, 1996) \\
\hline $433 \times 10^{3} \mathrm{~km}^{2}$ & $\begin{array}{c}138 \mathrm{Gta}^{-1} \\
0.35 \mathrm{ma}^{-1} \\
438 \times 10^{3} \mathrm{~km}^{2}\end{array}$ & $\begin{array}{c}120 \mathrm{Gta}^{-1} \\
0.32 \mathrm{ma}^{-1} \\
408 \times 10^{3} \mathrm{~km}^{2}\end{array}$ & 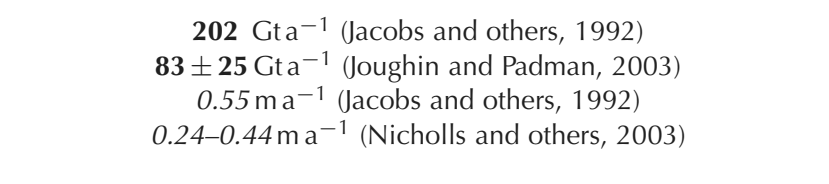 \\
\hline Brunt + Riiser-Larsen ('EWIS') & $\begin{array}{c}65 \mathrm{Gta}^{-1} \\
0.94 \mathrm{ma}^{-1} \\
77 \times 10^{3} \mathrm{~km}^{2}\end{array}$ & $\begin{array}{l}166 \mathrm{Gta}^{-1} \\
2.38 \mathrm{ma}^{-1} \\
76 \times 10^{3} \mathrm{~km}^{2}\end{array}$ & $\begin{array}{c}0.88 \mathrm{~m} \mathrm{a}^{-1} \text { (Thoma and others, 2006) } \\
<2.3 \mathrm{~m} \mathrm{a}^{-1} \text { (Fahrbach and others, 1994) }\end{array}$ \\
\hline Fimbulisen(+ Jelbart) & $\begin{array}{c}130 \mathrm{Gt} \mathrm{a}^{-1} \\
2.8 \mathrm{~m} \mathrm{a}^{-1} \\
53 \times 10^{3} \mathrm{~km}^{2}\end{array}$ & $\begin{array}{l}243 \mathrm{Gt} \mathrm{a}^{-1} \\
4.91 \mathrm{~m} \mathrm{a}^{-1} \\
54 \times 10^{3} \mathrm{~km}^{2}\end{array}$ & $\begin{array}{c}1.5-3.5 \mathrm{~m} \mathrm{a}^{-1} \text { (Smedsrud and others, 2006) } \\
0.85 \mathrm{~m} \mathrm{a}^{-1} \text { (Nicholls and others, 2008) }\end{array}$ \\
\hline $52.0 \times 10^{3} \mathrm{~km}^{2}$ & $\begin{array}{c}48 \mathrm{Gta}^{-1} \\
1.0 \mathrm{~m} \mathrm{a}^{-1} \\
52 \times 10^{3} \mathrm{~km}^{2}\end{array}$ & $\begin{array}{c}38 \mathrm{Gt} \mathrm{a}^{-1} \\
0.6 \mathrm{~m} \mathrm{a}^{-1} \\
66 \times 10^{3} \mathrm{~km}^{2}(\mathrm{~B}+\mathrm{C})\end{array}$ & $\begin{array}{l}\text { 15-70 Gt a } \\
0.27-1.26 \mathrm{~m} \mathrm{a}^{-1} \text { (Holland and others, 2009) } \\
0.35 \pm 0.19 \mathrm{~m} \mathrm{a}^{-1} \text { (Huhn and others, 2008) }\end{array}$ \\
\hline $23.4 \times 10^{3} \mathrm{~km}^{2}$ & $\begin{array}{l}86 \mathrm{Gta}^{-1} \\
3.6 \mathrm{ma}^{-1}\end{array}$ & $\begin{array}{l}22.5 \mathrm{Gt} \mathrm{a}^{-1} \\
0.43 \mathrm{ma}^{-1} \\
57 \times 10^{3} \mathrm{~km}^{2}\end{array}$ & 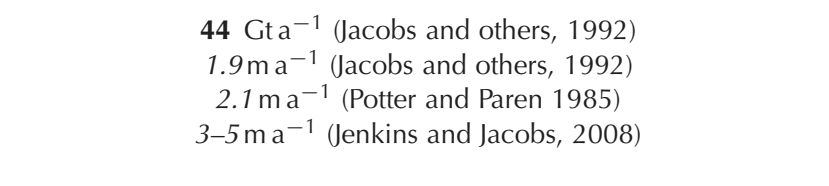 \\
\hline $51 \times 10^{3} \mathrm{~km}^{2}$ & $\begin{array}{l}13 \mathrm{Gta}^{-1} \\
3.1 \mathrm{~m} \mathrm{a}^{-1} \\
50 \times 10^{3} \mathrm{~km}^{2}\end{array}$ & & 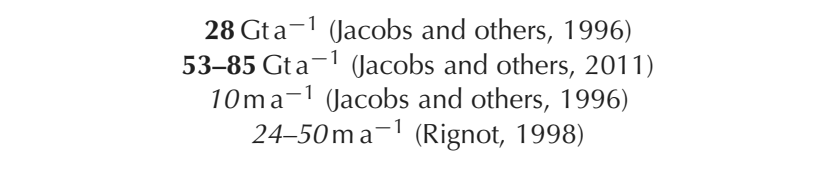 \\
\hline Getz IS & $\begin{array}{c}164 \mathrm{Gt} \mathrm{a}^{-1} \\
5.4 \mathrm{~m} \mathrm{a}^{-1} \\
35 \times 10^{3} \mathrm{~km}^{2}\end{array}$ & $\begin{array}{l}53.6 \mathrm{Gta}^{-1} \\
1.95 \mathrm{ma}^{-1} \\
30 \times 10^{3} \mathrm{~km}^{2}\end{array}$ & $128 \mathrm{Gta}^{-1}$ (personal communication from Jacobs, 2011) \\
\hline $470 \times 10^{3} \mathrm{~km}^{2}$ & $\begin{array}{c}260 \mathrm{Gt} \mathrm{a}^{-1} \\
0.6 \mathrm{ma}^{-1} \\
475 \times 10^{3} \mathrm{~km}^{2}\end{array}$ & $\begin{array}{c}180 \mathrm{Gt} \mathrm{a}^{-1} \\
0.49 \mathrm{~m} \mathrm{a}^{-1} \\
401 \times 10^{3} \mathrm{~km}^{2}\end{array}$ & $\begin{array}{c}81 \mathrm{Gta}^{-1} \text { (Jacobs and others, 1992) } \\
0.22 \mathrm{~m} \mathrm{a}^{-1} \text { (Jacobs and others, 1992) } \\
0.14 \mathrm{~m} \mathrm{a}^{-1} \text { (Dinniman and others, 2007) }\end{array}$ \\
\hline $65 \times 10^{3} \mathrm{~km}^{2}$ & $\begin{array}{c}2.9 \mathrm{~m} \mathrm{a}^{-1} \\
67 \times 10^{3} \mathrm{~km}^{2}\end{array}$ & $\begin{array}{c}0.35 \mathrm{ma}^{-1} \\
55 \times 10^{3} \mathrm{~km}^{2}\end{array}$ & 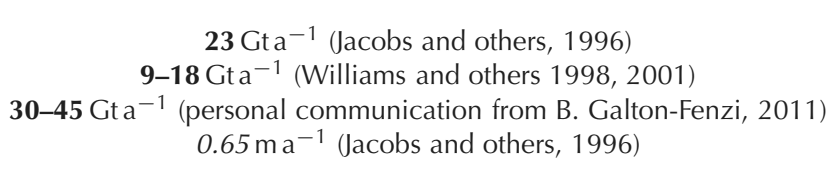 \\
\hline
\end{tabular}

sea level and the in situ freezing point is $0.9 \mathrm{~K}$ below the surface freezing point.

Marine ice is formed at rates of up to $0.6 \mathrm{~m} \mathrm{a}^{-1}$ north of Henry and Korff Ice Rises, and east of Fowler Peninsula. While the location of freezing areas is fully consistent with the observed locations of marine ice (Lambrecht and others, 2007), rates are smaller than estimates based on ice flux divergence (Joughin and Padman, 2003). Furthermore, marine ice formation in FESOM is stronger off Korff than off Henry Ice Rise, while the marine ice thickness map of Lambrecht and others (2007) suggests a stronger freezing north of Henry Ice Rise.

Two additional hotspots of marine ice formation (at rates of $0.5-1.0 \mathrm{~m} \mathrm{a}^{-1}$ ) are associated with the outflow of ice-shelf water (ISW) on the western sides of the Filchner and Ronne Troughs. For the Filchner Trough, the outflow of ISW and the formation of marine ice are consistent with the sub-ice flow pattern inferred by Nicholls and others (2001) and the 
glaciological findings of Grosfeld and others (1998), Joughin and Padman (2003) and Lambrecht and others (2007). For the Ronne Trough, evidence for marine ice formation exists for a narrow band along the coast (Nicholls and others, 2004).

A circulation regime with ISW outflow at the western side of the Ronne Trough has already been proposed by BRIOS simulations for anomalously strong sea-ice formation and dense water accumulation on the continental shelf north of Berkner Island (Timmermann and others, 2002b), suggesting that this may be part of a naturally occurring interannual variability. In our FESOM simulations, however, this pattern is persistent, which points to deficiencies in the density (salinity) distribution on the Weddell Sea's continental shelf in the model.

Area-mean net melt rate for the Filchner-Ronne Ice Shelf in the FESOM simulation is $0.35 \mathrm{~m} \mathrm{a}^{-1}$, which converts to a mass loss of $\sim 138 \mathrm{Gta}^{-1}$ (Table 1 ). These values are similar to the rates found in BRIOS (Hellmer, 2004) and are well within the range between the estimates of Jacobs and others (1992) and Joughin and Padman (2003); they are actually close to the centre of the range suggested from hydrographic observations by Nicholls and others (2003).

The importance of tides for the patterns and magnitudes of melting and freezing in an isopycnic model of the FilchnerRonne Ice Shelf cavity has been demonstrated by Makinson and others (2011). Even though FESOM does not consider tides, melt rate distribution and magnitudes in our simulation are much closer to their 'Tidal' case than to their 'Nontidal' simulation, and the area-mean melt rate in FESOM is considerably higher than in their 'Tidal' case. We conclude that even without explicitly modelling tides, their effect can, at least to some extent, be covered by an appropriate choice of turbulent heat/salt exchange coefficients.

\section{Eastern Weddell ice shelves}

For the mean melt rate of the Brunt and Riiser-Larsen Ice Shelves in the eastern Weddell Sea, Fahrbach and others (1994) suggested an upper limit of $2.3 \mathrm{ma}^{-1}$, which is consistent with estimates from glaciological field measurements along individual flowlines (Thomas, 1973; Gjessing and Wold, 1986). BRIOS estimates even slightly exceed this upper limit (Table 1). Due to a combination of coarse resolution and strongly smoothed model topography, the warm core of the coastal current in BRIOS simulations is not well enough separated from the EWIS base, leading to spuriously high melt rates in this sector.

The improved resolution in FESOM (Fig. 1) enables us to describe this region in a much more realistic way, with the coastal current being separated from the ice-shelf cavities, limiting the heat available for basal melting. Basal melting in FESOM averages to $0.94 \mathrm{~m} \mathrm{a}^{-1}$, which converts to a mass loss of $65 \mathrm{Gta}^{-1}$ and is well within the range suggested by the regional model of Thoma and others (2006).

\section{Fimbulisen}

Similar to the case for the Brunt and Riiser-Larsen Ice Shelves, and also for the same reasons, FESOM melt rates for Fimbulisen (including the Jelbart Ice Shelf) are considerably smaller than in BRIOS. FESOM's mean melt rate of $2.8 \mathrm{~m} \mathrm{a}^{-1}$ (converting to a mass loss of $130 \mathrm{Gta}^{-1}$ ) is still at the upper end of the range suggested by Smedsrud and others (2006), and considerably higher than in the model simulations of Nicholls and others (2008), who use a very similar model with different boundary conditions.

\section{Larsen Ice Shelf}

Since we use the RTopo- 1 ice-shelf configuration, only the Larsen C and a small remnant of the Larsen B ice shelf are present in our simulation (Fig. 6). Compared to the BRIOS model, where the Larsen ice shelves were crudely approximated as $200 \mathrm{~m}$ thick slabs of ice, the ice draft in FESOM is more realistic; the Larsen $\mathrm{C}$ ice shelf base extends down to more than $400 \mathrm{~m}$ below sea level. Basal melt rates for the Larsen $\mathrm{C}$ ice shelf in the FESOM simulations $\left(48 \mathrm{Gta}^{-1}\right.$ mass loss, $1.0 \mathrm{~m} \mathrm{a}^{-1}$ mean melting) are therefore considerably higher than in BRIOS, from which $38 \mathrm{Gta}^{-1}$ was obtained as a total for Larsen B and C (Table 1). Both rates are well within the range suggested by the plume model of Holland and others (2009); FESOM, however, is close to their 'warm case' (temperature increased by $0.5^{\circ} \mathrm{C}$ ), suggesting that FESOM shelf waters in this region are slightly too warm in the annual mean.

We have already mentioned the underestimation of summer sea-ice extent in the northwestern Weddell Sea (Fig. 4). Reduced summer sea-ice coverage is bound to cause spurious warming of surface waters, which come into contact with the northern part of the Larsen $C$ ice shelf and cause a strong seasonal increase in basal melting. As another consequence of this deficiency, formation of marine ice at the base of the Larsen $\mathrm{C}$ ice shelf does not occur in FESOM.

\section{Amundsen and Bellingshausen Seas}

\section{George VI Ice Shelf}

For the George VI Ice Shelf (Fig. 6), FESOM suggests a mean melt rate of $3.6 \mathrm{ma}^{-1}\left(86 \mathrm{Gta}^{-1}\right.$ mass loss), which is much higher than in BRIOS simulations and even exceeds the observation-based estimates of Potter and Paren (1985) and Jacobs and others (1992), but it is well within (actually at the lower end of) the range proposed by Jenkins and Jacobs (2008). The cavity circulation features near-bottom inflows at Ronne Entrance and in Marguerite Bay, recirculations in the northern and southern sectors of the cavity, and a northward flow along the ice-shelf base into Marguerite Bay. This agrees well with the observation-based findings of Jenkins and Jacobs (2008). Modelled temperatures at the bottom of Ronne Entrance (Fig. 7) clearly show the signature of warm water originating from Circumpolar Deep Water, but its temperature remains between 0 and $0.1^{\circ} \mathrm{C}$ (Fig. 7), which is $\sim 1^{\circ} \mathrm{C}$ too cold compared to observations.

\section{Abbot Ice Shelf}

Averaged basal melt for the Abbot Ice Shelf (Fig. 8) in our simulation is $2.1 \mathrm{ma}^{-1}$, corresponding to a mass loss of $59 \mathrm{Gta}^{-1}$, which is only slightly higher than an estimate derived from thickness and velocity measurements at the grounding line, the surface mass balance and an approximated calving rate (personal communication from E. Rignot, 2011). Sub-ice circulation features the classical cavity pattern with near-bottom inflows at Kings Peninsula and east of Thurston Island, a recirculation in the eastern basin, and outflows at the ice-shelf base, again at Kings Peninsula and east of Thurston Island.

\section{Pine Island Glacier (PIG)}

While Jacobs and others (1996) proposed $10 \mathrm{ma}^{-1}$ mean melting (28 Gta ${ }^{-1}$ mass loss), Jacobs and others (2011) deduced meltwater fluxes of 53 and $85 \pm 6 \mathrm{~km}^{3} \mathrm{a}^{-1}$ from hydrographic observations in 1994 and 2009, respectively. Satellite-based calculations by Rignot (1998) indicate basal 


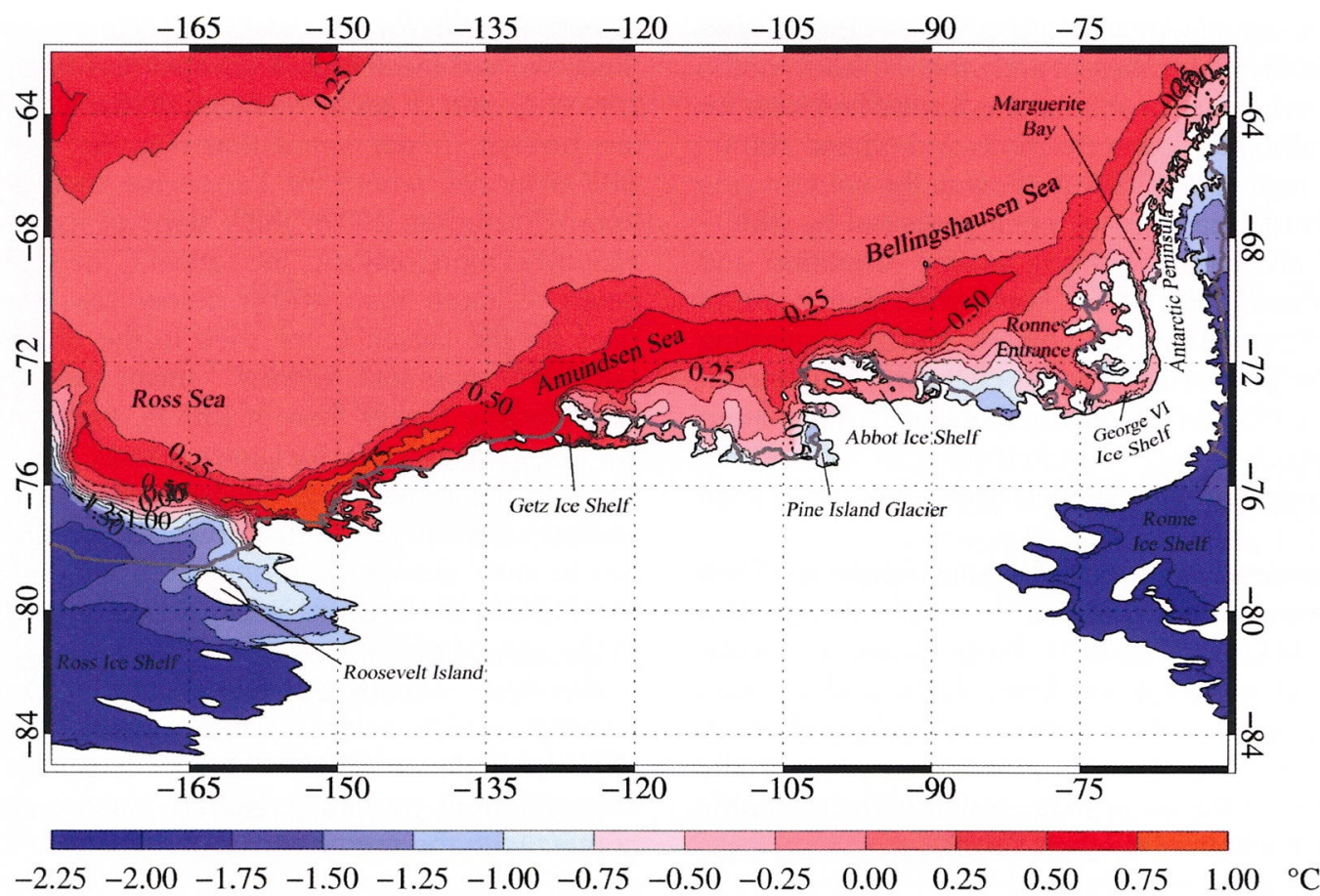

Fig. 7. Simulated bottom temperature $\left({ }^{\circ} \mathrm{C}\right)$ in the Amundsen and Bellingshausen Seas, averaged over 20 years of model simulation (1980-99).

melting of $50 \pm 10 \mathrm{~m} \mathrm{a}^{-1}$ locally within the $20 \mathrm{~km}$ wide tidal flexure zone adjacent to the grounding line, decreasing to an average of $24 \pm 4 \mathrm{ma}^{-1}$ between the hinge line and the calving front. FESOM mean melt rates near the grounding line do not exceed $7 \mathrm{ma}^{-1}$ (with the maximum melt rate located in the northeastern corner); the total mass loss of $13 \mathrm{Gta}^{-1}$ (corresponding to an average melt of $3.1 \mathrm{ma}^{-1}$ ) is too small. The reason for the mismatch is that near-bottom water masses in FESOM's Amundsen Sea embayment are much too cold: modelled bottom temperatures at the PIG ice front are around $-0.8^{\circ} \mathrm{C}$ (Fig. 7), while observations show that water of $\sim 1^{\circ} \mathrm{C}$ has access to the interior cavity (Jenkins and others, 2010). We attribute this deficiency mainly to a cold bias in the NCEP reanalysis winter temperatures, as

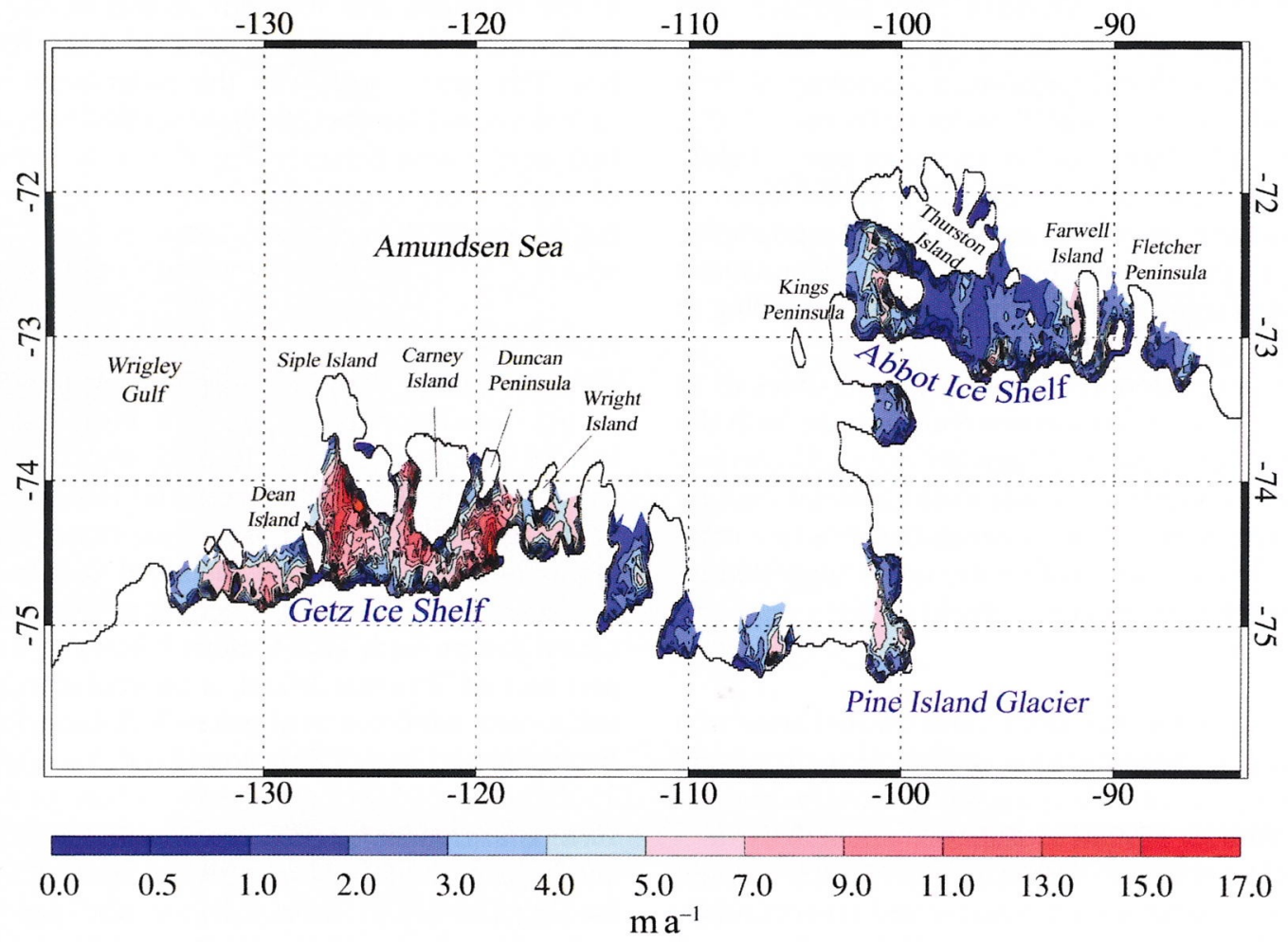

Fig. 8. Basal melt rates $\left(\mathrm{m} \mathrm{a}^{-1}\right)$ for the Amundsen Sea ice shelves, averaged over 20 years of model simulation (1980-99). Note the nonlinear colour scale. 
demonstrated by Assmann and others (2003). This cold bias induces spuriously high sea-ice formation, which through excessive salt release triggers deep convection and thus an erosion of the temperature maximum associated with the Circumpolar Deep Water on the continental shelf.

\section{Getz Ice Shelf}

Recent research indicates that the Getz Ice Shelf may be one of the major contributors of glacial meltwater in the Southern Ocean. Based on the years 1994-2009, S.S. Jacobs (personal communication, 2011) suggests that equilibrium basal mass loss may be as high as $80 \mathrm{Gta}^{-1}$, plus a disequilibrium melting of $\sim 48 \mathrm{Gta}^{-1}$. FESOM results propose an average basal mass loss of $164 \mathrm{Gta}^{-1}$, which corresponds to a mean melt rate of $5.4 \mathrm{~m} \mathrm{a}^{-1}$. Maximum melt rates exceed $15 \mathrm{~m} \mathrm{a}^{-1}$ and are located in the troughs around Siple and Carney Islands (Fig. 8). Water from the open ocean enters the cavity mainly via a bottom-intensified inflow west of Siple Island and a mid-depth inflow between Duncan Peninsula and Wright Island. Main outflow in our simulation occurs in the narrow passage between Siple and Carney Islands, and at the east coast of Dean Island.

Compared to hydrographic observations of Nathaniel B. Palmer cruise NBP0702 (personal communication from M. Schröder, 2011), FESOM bottom temperatures along the Getz Ice Shelf front are very close to reality west of Siple Island, while a cold bias (still related to the processes in Pine Island Bay) is evident along the eastern ice-shelf front. A comparison between cross-ice-front transports and observation-based estimates has not yet been made.

\section{Ross Ice Shelf}

Compared to many other ice shelves, basal melt rates for the Ross lce Shelf are rather modest. With a maximum draft of $700 \mathrm{~m}$, it does not reach as far below sea level as the Filcher-Ronne Ice Shelf does; maximum melt rates near the grounding line are therefore considerably lower. In FESOM, melt rates are up to $1 \mathrm{~m} \mathrm{a}^{-1}$ near the southern/southeastern grounding line (Fig. 9). Areas of marine ice formation with local maxima $>1 \mathrm{ma}^{-1}$ are located in the central part of the ice shelf. This distribution of freezing and melting is similar to the BRIOS experiments and the model simulations of Dinniman and others (2007).

The 20 year mean melt rate (Fig. 9) also features areas of strong melting along the ice front and in the areas east of Roosevelt Island and south of Ross Island. These are patterns of intense summer melting that are particularly pronounced in years with an anomalously low summer sea-ice coverage. The ramp-like approximation of the ice front in FESOM and an unavoidable smoothing of bottom topography lead to a substantial overestimation of shelf water inflow in these locations (also visible in Fig. 7). For the area east of Roosevelt Island, Hellmer and Jacobs (1995) obtained a mean basal melt rate of $0.18-0.27 \mathrm{~m} \mathrm{a}^{-1}$ from a two-dimensional model that had been optimized using hydrographic observations close to the ice front. This suggests that FESOM melt rates for this area are far too high.

Including the areas of spuriously high melting, mean basal mass loss is $260 \mathrm{Gta}^{-1}$ (corresponding to a mean melt rate of $0.6 \mathrm{ma}^{-1}$ ) and thus much larger than in BRIOS (180 Gta $\left.\mathrm{G}^{-1}, 0.49 \mathrm{ma}^{-1}\right)$, the estimate of Jacobs and others (1992) $\left(81 \mathrm{Gta}^{-1}, 0.22 \mathrm{~m} \mathrm{a}^{-1}\right)$ and the simulation of Dinniman and others (2007) $\left(\sim 0.14 \mathrm{~m} \mathrm{a}^{-1}\right)$. If we compute average basal melting excluding the high-melting months

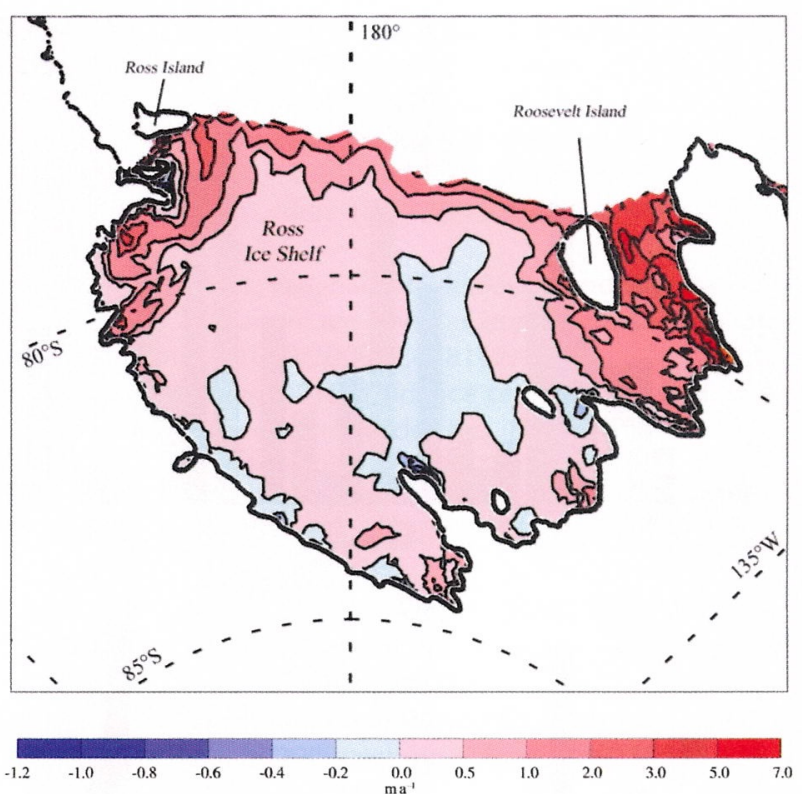

Fig. 9. Basal melt rates $\left(\mathrm{ma}^{-1}\right)$ for the Ross Ice Shelf averaged over 20 years of model simulation (1980-99). Note the nonlinear colour scale.

December-March, Ross Ice Shelf mean melting in FESOM reduces to $172 \mathrm{Gta}^{-1}\left(0.4 \mathrm{~m} \mathrm{a}^{-1}\right)$; a full 20 year average excluding the area east and southeast of Roosevelt Island and the area west of $168^{\circ} \mathrm{E}$ (but still considering the strong melting along the ice front) yields a basal mass loss of $115 \mathrm{Gta}^{-1}$ (mean melt rate of $0.37 \mathrm{~m} \mathrm{a}^{-1}$ ), which appears much more realistic. We conclude that basal melting under large parts of the Ross Ice Shelf is realistically simulated, with the exception of spuriously high melting occurring east of Roosevelt Island and south of Ross Island.

\section{Amery Ice Shelf}

Unlike the BRIOS model, the representation of the Amery Ice Shelf in FESOM benefits from the ice draft and ocean bathymetry data of Galton-Fenzi and others (2008), which have been incorporated in RTopo-1. This dataset is substantially improved over previous estimates of cavity geometry and features a much deeper ice draft (maximum $\sim 2500 \mathrm{~m}$ ) and bathymetry (maximum bottom depth in the cavity $\sim 3000 \mathrm{~m}$ ), while the maximum ice draft in BRIOS was only $700 \mathrm{~m}$, following Budd and others (1982). It is thus not surprising that melt rates calculated by FESOM are much larger than in BRIOS and also larger than the estimates of Jacobs and others (1996), who assumed an ice-shelf area of only $39 \times 10^{3} \mathrm{~km}^{2}$.

However, basal melting near the grounding line of the Amery Ice Shelf in FESOM exceeds $20 \mathrm{ma}^{-1}$, so that total basal mass loss amounts to $174 \mathrm{Gta}^{-1}$. This is much larger than any previous estimate, including results from the optimized high-resolution model of $\mathrm{B}$. Galton-Fenzi (personal communication, 2011) that uses the same cavity geometry (Table 1). In contrast to the Amundsen Sea embayment, where a cold bias is evident in FESOM's shelf waters, near-bottom waters in the model's Amery sector are too warm. Sensitivity studies with BRIOS (not shown) indicate that near-coast bottom temperatures in this region are very sensitive to the choice of atmospheric forcing fields and that Amery Ice Shelf basal melting may increase by a 

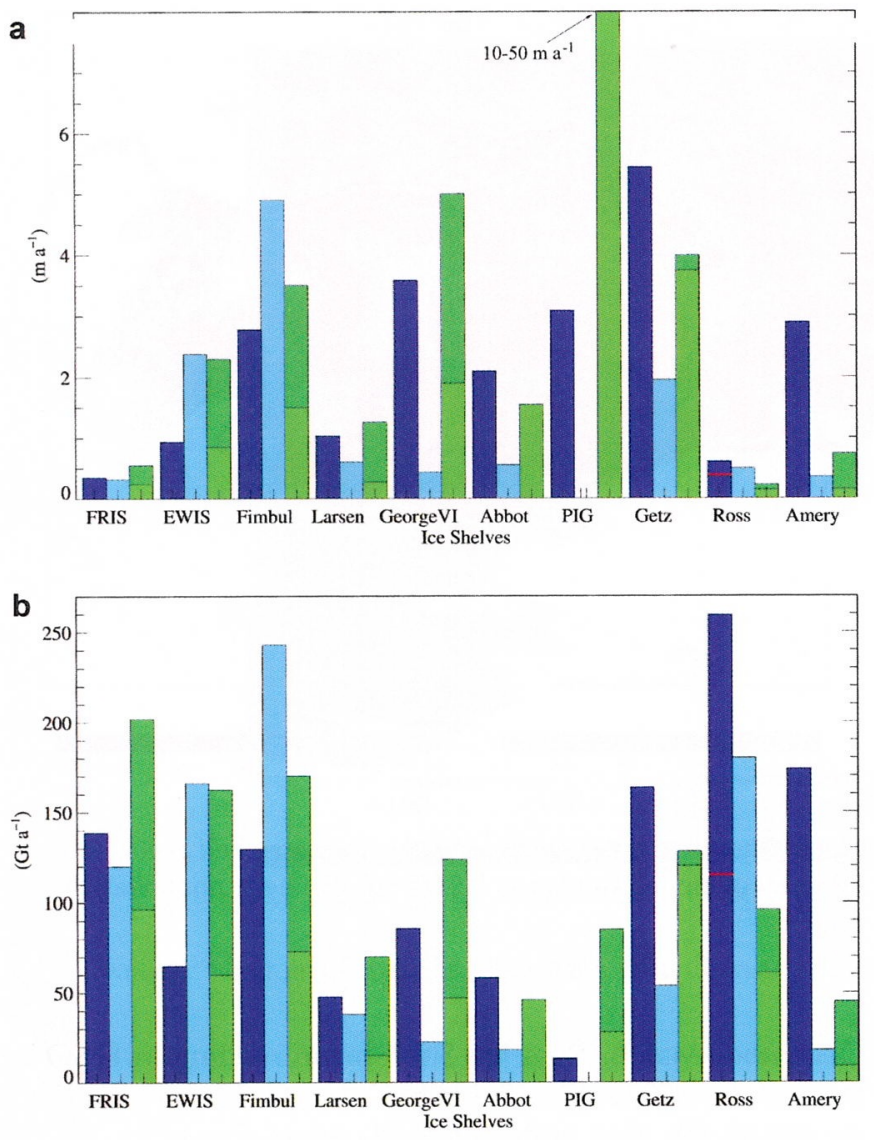

Fig. 10. (a) Basal melt rates $\left(\mathrm{ma}^{-1}\right)$ and (b) mass loss $\left(\mathrm{Gta}^{-1}\right)$ in FESOM (dark blue columns), BRIOS (light blue columns) and derived from independent estimates (observations or high-resolution models; green columns). The range of existing independent estimates is indicated in darker green. Note that a small range for independent estimates does not necessarily imply small uncertainties; it may also indicate the existence of only few studies (Table 1). The red lines in the FESOM columns for the Ross Ice Shelf indicate average values excluding the areas of spuriously high summer melting along the western and eastern margins of the ice shelf. Observed melt rates for PIG exceed the range of the $y$-axis chosen in (a). Sources and values are given in Table 1.

factor of 10 and more in situations with too little convection on the continental shelf. We conclude that the spuriously warm shelf water in this part of the FESOM model is likely to be caused by errors in the surface forcing, rather than by an overly smoothed bottom topography, although a combination of both is possible. In any case, estimates for Amery Ice Shelf basal melting must be treated with caution.

\section{SUMMARY, DISCUSSION AND OUTLOOK}

We have presented results from a global sea-ice/iceshelf/ocean model based on the finite-element method. The model has been used to quantify basal melt rates for the larger Antarctic ice shelves; most of them are in good agreement with observations or results from independent high-resolution models. Discrepancies can partly be attributed to deficiencies in the forcing data; possible improvements of sub-gridscale parameterizations, the representation of bottom topography/cavity geometry, and the consideration of tides are, however, still worthy of consideration.
A direct comparison between BRIOS and FESOM results (Fig. 10) reveals the tendency towards higher melt rates in places where more recent topographic data suggest thicker ice, i.e. a deeper ice-shelf base (e.g. the Larsen C and Amery ice shelves). In addition, the improved resolution in FESOM enables a substantial improvement in the representation of small cavities (e.g. the George VI, Abbot and Getz ice shelves). Where the fine resolution in FESOM allows better separation of the coastal current from the sub-iceshelf cavities (Fimbulisen and the Brunt and Riiser-Larsen Ice Shelves), modelled melt rates are reduced and appear more realistic. With the exception of the Amery Ice Shelf and the marginal sectors of the Ross Ice Shelf, melt rates and mass loss estimates from FESOM compare well with observations and with results from independent regional high-resolution models. In this respect, the finite-element approach has shown its potential to simulate processes on a horizontal scale of a few kilometres in a global model. The crucial importance of adequate atmospheric forcing has not changed, however, and neither has the challenge to obtain realistic sea-ice distributions and shelf water properties in a model without flux corrections or restoring.

Further errors have been found to arise from the uncertainties in ice-shelf draft and sea-bed topography. Although RTopo- 1 includes many of the most recent surveys in this area, numbers for depth and draft are not always well constrained. An even greater uncertainty arises from the unavoidable discretization and smoothing of topographies, especially along the ice front and the continental shelf break. Sensitivity studies (not shown) indicate that the choice of horizontal resolution and smoothing algorithms affects shelf water properties and flushing rates, and thus basal melt patterns, particularly for the Getz Ice Shelf and the eastern part of the Ross Ice Shelf.

Last but not least, the decision to keep the many small ice shelves along the coast in the model set-up proved to be a bad choice. The majority of these ice shelves are represented by only one line of elements, which is clearly insufficient to resolve sub-ice- and ice-front hydrography in an adequate way. Because these ice shelves are typically much more exposed to ocean heat than the larger, more secluded, ice shelves and they add up to a considerable area (both in FESOM and in reality; Table 1), they are responsible for a spuriously high total ice-shelf basal mass loss in the model. In reality, many of these ice shelves lose mass mainly by calving of small icebergs, which melt in the marginal seas and thus provide a similar freshwater signal.

Our study reflects the importance of Amundsen Sea ice shelves for Antarctica's ice mass budget. Some of the highest basal melt rates are found in this drainage region for the West Antarctic ice sheet. The Getz Ice Shelf appears as a major source of meltwater in our simulation; its contribution is roughly equal to the much larger Filchner-Ronne and Ross Ice Shelves (if we consider realistic numbers for Ross Ice Shelf melting; see the discussion of Ross Ice Shelf melt rates for details). While to date the Ross and Fichner-Ronne Ice Shelves appear much less vulnerable than the 'warm water' ice shelves of the Amundsen Sea, their potential fate in a warmer climate deserves further investigation.

\section{ACKNOWLEDGEMENTS}

We thank K. Assmann, B. Galton-Fenzi, S.S. Jacobs and M. Schröder for enlightening discussions, W. Cohrs, V. Haid 
and D. Sidorenko for technical help and support, and the anonymous reviewers for helpful comments and suggestions. The NCEP/NCAR reanalysis data were provided by the NOAA's Cooperative Institute for Research in Environmental Sciences Climate Diagnostics Center, Boulder, online at http://www.cdc.noaa.gov. This work was supported by funding to the ice2sea programme from the European Union 7th Framework Programme, grant No. 226375. This is ice2sea contribution No.ice2sea42.

\section{REFERENCES}

Assmann K, Hellmer HH and Beckmann A (2003) Seasonal variation in circulation and water mass distribution on the Ross Sea continental shelf. Antarct. Sci., 15(1), 3-11 (doi: 10.1017/S0954102003001007)

Beckmann A, Hellmer HH and Timmermann R (1999) A numerical model of the Weddell Sea: large-scale circulation and water mass distribution. J. Geophys. Res., 104(C10), 23 375-23 392 (doi: 10.1029/1999JC900194)

Budd WF, Corry MJ and Jacka TH (1982) Results from the Amery Ice Shelf Project. Ann. Glaciol., 3, 36-41

Cavalieri D, Parkinson C, Gloersen P and Zwally HJ (2006) Sea ice concentrations from Nimbus-7 SMMR and DMSP SSM/I-SSMIS passive microwave data, January 1979-June 2006. National Snow and Ice Data Center, Boulder, CO. Digital media

Dinniman MS, Klinck JM and Smith WO (2007) Influence of sea ice cover and icebergs on circulation and water mass formation in a numerical circulation model of the Ross Sea, Antarctica. J. Geophys. Res., 112(C11), C11013 (doi: 10.1029/ 2006JC004036)

Fahrbach E, Peterson RG, Rohardt G, Schlosser P and Bayer R (1994) Suppression of bottom water formation in the southeastern Weddell sea. Deep-Sea Res. I, 41(2), 389-411 (doi: 10.1016/09670637(94)90010-8)

Fahrbach E, Hoppema M, Rohardt G, Boebel O, Klatt O and Wisotzki A (2011) Warming of deep and abyssal water masses along the Greenwich meridian on decadal time scales: the Weddell gyre as a heat buffer. Deep-Sea Res. II, 58(25-26), 2509-2523 (doi: 10.1016/j.dsr2.2011.06.007)

Galton-Fenzi BK, Maraldi C, Coleman R and Hunter J (2008) The cavity under the Amery Ice Shelf, East Antarctica. J. Glaciol., 54(188), 881-887 (doi: 10.3189/002214308787779898)

Gerdes R, Determann J and Grosfeld K (1999) Ocean circulation beneath Filchner-Ronne Ice Shelf from three-dimensional model results. J. Geophys. Res., 104(C7), 15 827-15 842 (doi: 10.1029/1999JC900053)

Gjessing Y and Wold B (1986) Absolute movements, mass balance and snow temperatures of the Riiser-Larsenisen Ice Shelf, Antarctica. Nor. Polarinst. Skr., 187, 23-31

Grosfeld K, Hellmer HH, Jonas M, Sandhäger H, Schulte $M$ and Vaughan DG (1998) Marine ice beneath Filchner Ice Shelf: evidence from a multi-disciplinary approach. In Jacobs SS and Weiss RF eds. Ocean, ice and atmosphere: interactions at the Antarctic continental margin. American Geophysical Union, Washington, DC, 319-339

Grosfeld K, Schröder M, Fahrbach E, Gerdes R and Mackensen A (2001) How iceberg calving and grounding change the circulation and hydrography in the Filchner Ice Shelf-Ocean System. J. Geophys. Res., 106(C5), 9039-9055 (doi: 10.1029/ 2000JC000601)

Hellmer HH (2004) Impact of Antarctic ice shelf basal melting on sea ice and deep ocean properties. Geophys. Res. Lett., 31(10), L10307 (doi: 10.1029/2004GL019506)

Hellmer HH and Jacobs SS (1995) Seasonal circulation under the eastern Ross Ice Shelf, Antarctica. J. Geophys. Res., 100(C6), 10 873-10 885 (doi: 10.1029/95JC00753)
Hellmer HH and Olbers DJ (1989) A two-dimensional model for the thermohaline circulation under an ice shelf. Antarct. Sci., 1(4), 325-336 (doi: 10.1017/S0954102089000490)

Holland DM and Jenkins A (1999) Modeling thermodynamic iceocean interactions at the base of an ice shelf. J. Phys. Oceanogr., 29(8), 1787-1800 (doi: 10.1175/1520-0485(1999)029<1787: MTIOIA $>2.0 . \mathrm{CO}$;2)

Holland PR, Corr HFJ, Vaughan DG, Jenkins A and Skvarca P (2009) Marine ice in Larsen Ice Shelf. Geophys. Res. Lett., 36(11), L11604 (doi: 10.1029/2009GL038162)

Huhn $O$ and 6 others (2010) Evidence of deep- and bottom-water formation in the western Weddell Sea. Deep-Sea Res. II, 55(8-9), 1098-1116 (doi: 10.1016/j.dsr2.2007.12.015)

Jacobs SS, Hellmer HH, Doake CSM, Jenkins A and Frolich RM (1992) Melting of ice shelves and the mass balance of Antarctica. J. Glaciol., 38(130), 375-387

Jacobs SS, Hellmer HH and Jenkins A (1996) Antarctic ice sheet melting in the southeast Pacific. Geophys. Res. Lett., 23(9), 957-960 (doi: 10.1029/96GL00723)

Jacobs SS, Giulivi CF and Mele PA (2002) Freshening of the Ross Sea during the late 20th century. Science, 297(5580), 386-389 (doi: 10.1126/science.1069574)

Jacobs SS, Jenkins A, Giulivi CF and Dutrieux P (2011) Stronger ocean circulation and increased melting under Pine Island Glacier ice shelf. Nature Geosci., 4(8), 519-523 (doi: 10.1038/ ngeo1188)

Jenkins A (1991) A one-dimensional model of ice shelf-ocean interaction. J. Geophys. Res., 96(C11), 20671-20677 (doi: 10.1029/91JC01842)

Jenkins A and Jacobs S (2008) Circulation and melting beneath George VI Ice Shelf, Antarctica. J. Geophys. Res., 113(C4), C04013 (doi: 10.1029/2007JC004449)

Jenkins A and 6 others (2010) Observations beneath Pine Island Glacier in West Antarctica and implications for its retreat. Nature Geosci., 3(7), 468-472 (doi: 10.1038/ngeo890)

Joughin I and Padman L (2003) Melting and freezing beneath Filchner-Ronne Ice Shelf, Antarctica. Geophys. Res. Lett., 30(9), 1477-1480 (doi: 10.1029/2003GL016941)

Lambrecht A, Sandhager H, Vaughan DG and Mayer C (2007) New ice thickness maps of Filchner-Ronne Ice Shelf, Antarctica, with specific focus on grounding lines and marine ice. Antarct. Sci., 19(4), 521-532 (doi: 10.1017/S0954102007000661)

Makinson K, Holland PR, Jenkins A, Nicholls KW and Holland DM (2011) Influence of tides on melting and freezing beneath Filchner-Ronne Ice Shelf, Antarctica. Geophys. Res. Lett., 38(6), L06601 (doi: 10.1029/2010GL046462)

Nicholls KW, Østerhus S, Makinson K and Johnson MR (2001) Oceanographic conditions south of Berkner Island, beneath Filchner-Ronne Ice Shelf, Antarctica. J. Geophys. Res., 106(C6), 11 481-11 492 (doi: 10.1029/2000JC000350)

Nicholls KW, Padman L, Schröder M, Woodgate RA, Jenkins A and Østerhus S (2003) Water mass modification over the continental shelf north of Ronne Ice Shelf, Antarctica. J. Geophys. Res., 108(C8), 3260 (doi: 10.1029/2002JC001713)

Nicholls KW, Makinson K and Østerhus S (2004) Circulation and water masses beneath the northern Ronne Ice Shelf, Antarctica. J. Geophys. Res., 109(C12), C12017 (doi: 10.1029/2004JC002302)

Nicholls KW, Abrahamsen EP, Heywood KJ, Stansfield K and Østerhus S (2008) High-latitude oceanography using the Autosub autonomous underwater vehicle. Limnol. Oceanogr., 53(5, Pt 2), 2309-2320

Potter JR and Paren JG (1985) Interaction between ice shelf and ocean in George VI Sound, Antarctica. In Jacobs SS ed. Oceanology of the Antarctic continental shelf. American Geophysical Union, Washington, DC, 35-58

Rignot EJ (1998) Fast recession of a West Antarctic glacier. Science, 281(5376), 549-551 (doi: 10.1126/science.281.5376.549)

Rignot E and Jacobs S (2008) Ice-shelf melting around Antarctica. Am. Geophys. Union, Fall Meet. [Abstr. C41D-02] 
Smedsrud LH, Jenkin A, Holland DM and Nost OA (2006) Modeling ocean processes below Fimbulisen, Antarctica. J. Geophys. Res., 111(C1), C01007 (doi: 10.1029/2005JC002915)

Thoma M, Grosfeld K and Lange MA (2006) Impact of the Eastern Weddell Ice Shelves on water masses in the eastern Weddell Sea. J. Geophys. Res., 111(C12), C12010 (doi: 10.1029/ 2005JC003212)

Thomas RH (1973) The dynamics of the Brunt Ice Shelf, Coats Land, Antarctica. Br. Antarct. Surv. Sci. Rep. 79

Timmermann R, Beckmann A and Hellmer HH (2001) The role of sea ice in the fresh-water budget of the Weddell Sea, Antarctica. Ann. Glaciol., 33, 419-424 (doi: 10.3189/172756401781818121)

Timmermann R, Beckmann A and Hellmer HH (2002a) Simulations of ice-ocean dynamics in the Weddell Sea 1. Model configuration and validation. J. Geophys. Res., 107(C3), 3024 (doi: 10.1029/2000JC000741)

Timmermann R, Hellmer HH and Beckmann A (2002b) Simulations of ice-ocean dynamics in the Weddell Sea 2. Interannual variability 1985-1993. J. Geophys. Res., 107(C3), 3025 (doi: 10.1029/2000JC000742)
Timmermann R, Danilov S, Schröter J, Böning C, Sidorenko D and Rollenhagen K (2009) Ocean circulation and sea ice distribution in a finite element global sea ice-ocean model. Ocean Model., 27(3-4), 114-129 (doi: 10.1016/j.ocemod.2008. 10.009)

Timmermann R and 16 others (2010) A consistent data set of Antarctic ice sheet topography, cavity geometry, and global bathymetry. Earth Syst. Sci. Data, 2(2), 261-273 (doi: 10.5194/ essd-2-261-2010)

Vaughan DG, Bamber JL, Giovinetto MB, Russell J and Cooper APR (1999) Reassessment of net surface mass balance in Antarctica. J. Climate, 12(4), 933-946 (doi: 10.1175/15200442(1999)012<0933:RONSMB > 2.0.CO;2)

Williams MJM, Warner RC and Budd WF (1998) The effects of ocean warming on melting and ocean circulation under the Amery Ice Shelf, East Antarctica. Ann. Glaciol., 27, 75-80

Williams MJM, Grosfeld K, Warner RC, Gerdes R and Determann J (2001) Ocean circulation and ice-ocean interaction beneath the Amery Ice Shelf, Antarctica. J. Geophys. Res., 106(C10), 22383 22399 (doi: 10.1029/2000JC000236) 